\title{
Pengembangan Bahan Ajar Matematika Berbasis PMRI Pada Materi Kubus Dan Balok Kelas VIII
}

\author{
Efuansyah $^{1)}$, Reny Wahyuni' ${ }^{2}$ \\ 1Zxfe73@yahoo.co.id \\ ${ }^{2}$ Renywahyuni264@gmail.com \\ ${ }^{1,2}$ FKIP, STKIP-PGRI Lubuklinggau
}

\begin{abstract}
The purpose of this research is to develop teaching materials use Approach of Indonesian Realistic Mathematics (PMRI) on Cube and cuboid material for grade VIII students of SMP Negeri 13 Lubuklinggau and to know the quality of teaching material is seen from aspect of validity and practicability. RME or in Indonesia is better known by PMRI is a learning approach mathematics oriented to everyday life close to the world of students, it aims to make it easier for students to understand problems and solve mathematical problems. This research is a development research with the development model of ADDIE ( Analysis, Design, Development, Implementation, Evaluation). phase analysis includes student needs analysis and curriculum analysis, the design phase includes the preparation of the map needs of teaching materials, the establishment of teaching materials structure and the making of research instruments. Development phase includes the preparation of teaching materials and validation of teaching materials on the expert, the implementation phase includes teaching experiments on 3 students (one to one), small group (small group) and field test. The evaluation phase includes the assessment of teaching materials by teachers and students. The research used Approach of Indonesian Realistic Mathematics (PMRI) on cube and cuboid material, the result of research showed that (1) the quality of teaching material is seen from aspect of validity and practicality included in criterion either based on four expert lecturer (Expert Content / Mathematics, Media Expert and Expert Language).
\end{abstract}

Keywords: PMRI, Cube, Cuboid, ADDIE

\section{Pendahuluan}

Matematika merupakan salah satu mata pelajaran yang diajarkan pada setiap jenjang pendidikan. Dengan mempelajari matematika mempersiapkan peserta didik agar dapat bersaing dengan menggunakan pola pikir yang kreatif, inovatif dan imajinatif (Utami, Mukhni, \& Jazwinarti, 2014:7). Berdasarkan data dari National Council of Teachers of Mathematics/NCTM Ratnaningsih (2008:129) terdapat lima proses standar bagi peserta didik dalam memperoleh dan menggunakan pengetahuan matematik yaitu: pemecahan masalah (problem solving), penalaran dan pembuktian (reasoning and proof), komunikasi (communication), koneksi (connection), dan representasi (representation). Dengan memperhatikan hal tersebut, maka perlu dikembangkan proses berpikir dan bernalar peserta didik dalam pembelajaran matematika untuk pengembangan diri peserta didik di 
masa datang. Pada Standar Isi (SI) Mata Pelajaran Matematika SMP/MTs dinyatakan bahwa pada setiap kesempatan, pembelajaran matematika hendaknya dimulai dengan pengenalan masalah yang sesuai dengan situasi (contextual problem). Akan tetapi, pada kenyataan yang terjadi di lapangan adalah sekolah-sekolah dalam mengelola pembelajaran matematika belum mengacu pada tujuan mata pelajaran matematika yang ditetapkan dalam Standar Isi (SI).

Dalam konteks pembelajaran, bahan ajar merupakan komponen yang harus ada dalam proses pembelajaran, karena bahan ajar merupakan pedoman dalam memahami suatu materi pembelajaran. Tanpa adanya bahan ajar maka pembelajaran tidak akan menghasilkan apa-apa. Berdasarkan kenyataan di sekolah didapat bahwa bahan ajar pada pembelajaran matematika masih bersifat abstrak, bahan ajar yang ada hanya menampilkan rumus dan soal-soal saja. Sehingga bahan ajar tersebut belum membantu siswa dalam proses berpikir dan pembelajaran matematika menjadi tidak bermakna. Hal senada diungkapkan oleh Haji (2011:45) yang menyatakan bahwa penyajian materi yang tertulis pada buku-buku matematika yang digunakan saat ini tersusun sebagai berikut: 1 . definisi (pengertian konsep), 2. contoh soal, dan 3. latihan Soal. Penulis menjelaskan pengertian (definisi) suatu konsep dalam matematika. Kemudian, penulis memberikan contoh penerapan konsep tersebut, dan diakhiri dengan memberikan soal latihan. Ketiga tahapan penulisan buku tersebut didominasi oleh penulis, sedangkan siswa (pembaca) bersikap pasif memahami dan mengerjakan soal yang dijelaskan dan diperintahkan oleh penulis. Selain itu, buku-buku (bahan ajar) matematika tersebut tidak memuat soal-soal non rutin serta tidak menantang siswa untuk melakukan kegiatan refleksi, eksperimen, eksplorasi, inkuiri, konjektur, dan generalisasi. Bahan yang disajikan monoton dan soalsoalnya bersifat rutin.

Berbagai macam upaya telah dan masih dilakukan oleh guru-guru matematika dan para peneliti untuk melatih kemampuan penalaran matematika siswa pada sekolah menengah pertama, salah satunya dengan menggunakan pendekatan Pendidikan Matematika Realistik (PMR). PMR atau istilah asingnya disebut dengan Realistic Mathematics Education (RME) atau di Indonesia lebih dikenal dengan sebutan Pendidikan Matematika Realistik Indonesia (PMRI). Pendidikan Matematika Realistik Indonesia" merupakan bentuk pembelajaran yang menggunakan dunia nyata dan kegiatan pembelajaran yang lebih menekankan aktivitas siswa untuk mencari, menemukan, dan membangun sendiri pengetahuan yang diperlukan sehingga pembelajaran menjadi terpusat pada siswa (Muchlis, 2012:136). Sedangkan menurut Aisyah, dkk (Kusumaningtyas, Wardono, \& Sugiarto, 2013:2) dalam pendekatan PMRI ini, kelas 
matematika bukan tempat memindahkan matematika dari guru kepada peserta didik, melainkan tempat peserta didik menemukan kembali ide dan konsep matematika melalui eksplorasi masalah-masalah nyata. Dunia nyata digunakan sebagai titik awal pembelajaran matematika. Untuk menekankan bahwa proses lebih penting daripada hasil, dalam pendekatan matematika realistik digunakan istilah matematisasi, yaitu proses mematematikakan dunia nyata. Sehingga memudahkan siswa dalam menyelesaikan permasalahan matematika.

Salah satu kegiatan pembelajaran yang mampu mempengaruhi aktivitas pembelajaran adalah dengan memasukkan bahan ajar dalam aktivitas tersebut. Bahan ajar yang didesain sesuai dengan kurikulum dan kebutuhan siswa dapat membantu siswa dalam memahami pembelajaran matematika dengan baik, sehingga diharapkan siswa merasa senang dan termotivasi dalam mengikuti pelajaran matematika. Dalam hal ini, perlu dikembangkan bahan ajar matematika yang sesuai dengan tuntutan kurikulum dan kebutuhan siswa. Dimana bahan ajar tersebut dekat dengan kehidupan nyata siswa dan berawal dari permasalahan dalam lingkungan sekitar siswa yang dapat mempermudah siswa dalam memahami konsep matematika yang abstrak, sehingga melalui pembelajaran tersebut dapat mengembangkan kemampuan berpikir matematis siswa dengan baik.

\section{Metode Penelitian}

Jenis penelitian ini merupakan penelitian pengembangan yaitu suatu penelitian yang bertujuan menghasilkan produk (prototype) dan menguji kualitas produk tersebut. Produk yang dihasilkan dalam penelitian ini adalah bahan ajar dengan pendekatan PMRI berupa buku siswa dan buku guru. Model penelitian pengembangan yang digunakan dalam penelitian ini adalah model pengembangan ADDIE (Analysis, Design, Development, Implementation, and Evaluation). Subjek penelitian ini adalah SMP N 13 Lubuklinggau kelas VIII tahun ajaran 2016/2017.

\subsection{Teknik Pengumpulan Data}

Teknik pengumpulan data pada penelitian ini adalah :

\subsubsection{Walkthrough}

Walkthrough dilakukan terhadap pakar (expert) dan digunakan untuk memvalidasi bahan ajar yang meliputi konten, konstruk dan bahasa. Saran dan komentar selama Walkthrough pada tahap expert review digunakan untuk merevisi prototipe 1 dan 
digabungkan dengan saran dan komentar pada tahap one to one untuk menghasilkan prototipe 2 .

\subsubsection{Dokumentasi}

Dokumentasi ini dilakukan dengan mengumpulkan data-data yang diperoleh berupa dokumen tertulis maupun gambar yang mendukung dalam penelitian. Dokumentasi berupa gambar dan video dilakukan pada tahap one to one, small group, dan field test.

\subsection{Teknik Analisis Data}

\subsubsection{Analisis data Walkthrough}

Untuk menganalisis data validasi pakar digunakan analisis deskriptif dengan cara merevisi bahan ajar berdasarkan saran dan komentar dari pakar. Saran dan komentar dari pakar digunakan untuk merevisi bahan ajar digabungkan dengan saran dan komentar siswa pada tahap one to one.

\subsubsection{Analisis dokumen}

Untuk menganalisis data kepraktisan bahan ajar digunakan analisis deskriptif. Data analisis berdasarkan dokumen tertulis dan gambar yang diperoleh peneliti selama penelitian

\section{Hasil Dan Pembahasan}

\subsection{Hasil Pengembangan Bahan Ajar}

Penelitian pengembangan ini menghasilkan bahan ajar berupa buku siswa yang berbasis pendekatan PMRI (Pendekatan Matematika Realistik Indonesia) pada siswa SMP N 13 Lubuklinggau. Penelitian ini menggunakan model pengembangan ADDIE, prosedur yang dilakukan dalam penelitian ini meliputi 5 tahapan yaitu analysis, development, design, implementation dan evaluation. Setiap tahapan penelitian ini dijelaskan sebagai berikut:

\subsubsection{Tahap Analisis (Analysis)}

Pada tahap ini kegiatan yang dilakukan meliputi analisis subjek penelitian, analisis kurikulum dan pembuatan instrumen. Berikut pembahasan masing-masing tahap dalam analysis.

a. Analisis subjek penelitian

Pada tahap ini peneliti melakukan analisis terhadap siswa yang akan dijadikan subjek penelitian dan juga merupakan kelas uji coba penggunaan bahan ajar yang dikembangkan 
Pengembangan Bahan Ajar Matematika Berbasis PMRI Pada Materi Kubus Dan Balok Kelas VIII

Efuansyah dan Reny Wahyuni

berbasis pendekatan PMRI. Siswa yang dijadikan subjek penelitian ini adalah siswa kelas VIII.4 SMP Negeri 13 Lubuklinggau yang berjumlah 20 siswa. Analisis subjek penelitian ini bertujuan untuk mengetahui jumlah siswa dan informasi bahwa kelas VIII.4 belum pernah menerima / menggunakan bahan ajar berbasis pendekatan PMRI dan dari guru diperoleh informasi bahwa tingkat kemampuan siswa pada kelas VIII SMP Negeri 13 Lubuklinggau adalah heterogen. Dalam analisis subjek penelitian juga ditentukan kriteria siswa yang akan dipilih untuk dilaksanakan tahap one to one yaitu 1 orang siswa berkemampuan rendah, 1 orang siswa berkemampuan sedang dan 1 orang siswa berkemampuan tinggi.

\section{b. Analisis Kurikulum}

Analisis kurikulum bertujuan untuk mengetahui Standar Kompetensi (SK), Kompetensi Dasar (KD), serta indikator yang digunakan dalam pengembangan bahan ajar berbasis pendekatan PMRI. Kurikulum yang digunakan dalam pengembangan bahan ajar ini adalah kurikulum KTSP (Kurikulum Tingkat Satuan Pendidikan). Dari analisis kurikulum tersebut aspek yang dikembangkan dalam bahan ajar berbasis pendekatan PMRI ini adalah geometri dan pengukuran pada pokok bahasan volume bangun ruang sisi datar khusus nya materi kubus dan balok.

Adapun Standar Kompetensi (SK) dan Kompetensi Dasar (KD) untuk materi volume bangun ruang sisi datar di kelas VIII dapat dilihat pada tabel 1 di bawah ini.

\section{Tabel 1}

\section{Standar Kompetensi dan Kompetensi Dasar Materi Bangun Ruang Sisi Datar}

\begin{tabular}{llll}
\hline Standar Kompetensi & Kompetensi Dasar & & \\
\hline 5. Memahami sifat-sifat kubus, balok, & 5.3 & Menghitung luas permukaan dan \\
prisma, limas dan bagian-bagiannya, & volume kubus, balok, prisma dan \\
serta menentukan ukurannya. & limas. & & \\
\hline
\end{tabular}

Pada penelitian ini, kompetensi dasar yang dikembangkan menjadi bahan ajar berbasis pendekatan PMRI adalah KD 5.3. Adapun indikator-indikator tersebut adalah menyelesaikan masalah sehari-hari yang berkaitan dengan konsep luas permukaan kubus, menyelesaikan masalah sehari-hari yang berkaitan dengan konsep luas permukaan balok, menyelesaikan masalah sehari-hari yang berkaitan dengan konsep volume kubus, menyelesaikan masalah sehari-hari yang berkaitan dengan konsep volume balok. 


\subsubsection{Tahap Desain (Design)}

Hasil dari tahapan analisis dijadikan sebagai dasar dalam membuat desain bahan ajar. Hal-hal yang dilakukan pada tahap desain yaitu menyusun peta kebutuhan bahan ajar dan melakukan validasi kepada para ahli. Proses yang dilakukan pada tahapan ini, yaitu :

\section{a. Menyusun peta kebutuhan bahan ajar}

Penyusunan peta kebutuhan bahan ajar dilakukan dengan memperhatikan Standar Kompetensi dan Kompetensi Dasar serta indikator pencapaian kompetensi. Peta kebutuhan bahan ajar ini disusun untuk memudahkan peneliti dalam mengurutkan materi yang akan disajikan dalam bahan ajar.

b. Validasi para ahli

Pada tahap ini, peneliti mengevaluasi kembali bahan ajar yang telah dibuat baik dari segi konten, konstruk dan bahasa yang digunakan. Setelah dibaca dan dievaluasi maka menghasilkan prototype pertama yang difokuskan pada konten, konstruk dan bahasa.

1) Expert Review

Setelah prototype pertama jadi, maka tahap selanjutnya adalah expert review (Uji coba pakar). Tahapan ini bertujuan untuk memperoleh bahan ajar yang valid. Prototype 1 yang diberikan kemudian divalidasi dari segi konten, konstruk dan bahasa. Adapun beberapa komnetar dari para pakar sebagai validator tersebut adalah sebagai berikut :

- Dr. Somakim, M.Pd. Dosen Pendidikan Matematika UNSRI

- Dr. Ely Susanti, M.Pd. Dosen Pendidikan Matematika UNSRI

- Tri Astuti, M.Pd Dosen Pendidikan Bahasa Indonesia STKIP PGRI LLG

- Dodik Mulyono, M.Pd. Dosen Pendididkan Matematika STKIP PGRI LLG

Adapun komentar dan saran dari pakar sebagai validator peneliti rangkum pada tabel 2.

Tabel 2

Komentar dan Saran Validator terhadap Bahan Ajar

\begin{tabular}{|c|c|c|}
\hline No & Validator & Komentar/Saran \\
\hline 1. & Dr. Somakim, M.Pd. & * Sesuaikan harga pada soal dengan kehidupan nyata \\
\hline & & $\begin{array}{l}\text { * Pada permasalahan } 4 \text { untuk luas permukaan kubus } \\
\text { dan balok, pada soal no } 3 \text { dibuang saja karena } \\
\text { maknanya sama dengan soal no } 2\end{array}$ \\
\hline
\end{tabular}


Pengembangan Bahan Ajar Matematika Berbasis PMRI Pada Materi Kubus Dan Balok Kelas VIII

Efuansyah dan Reny Wahyuni

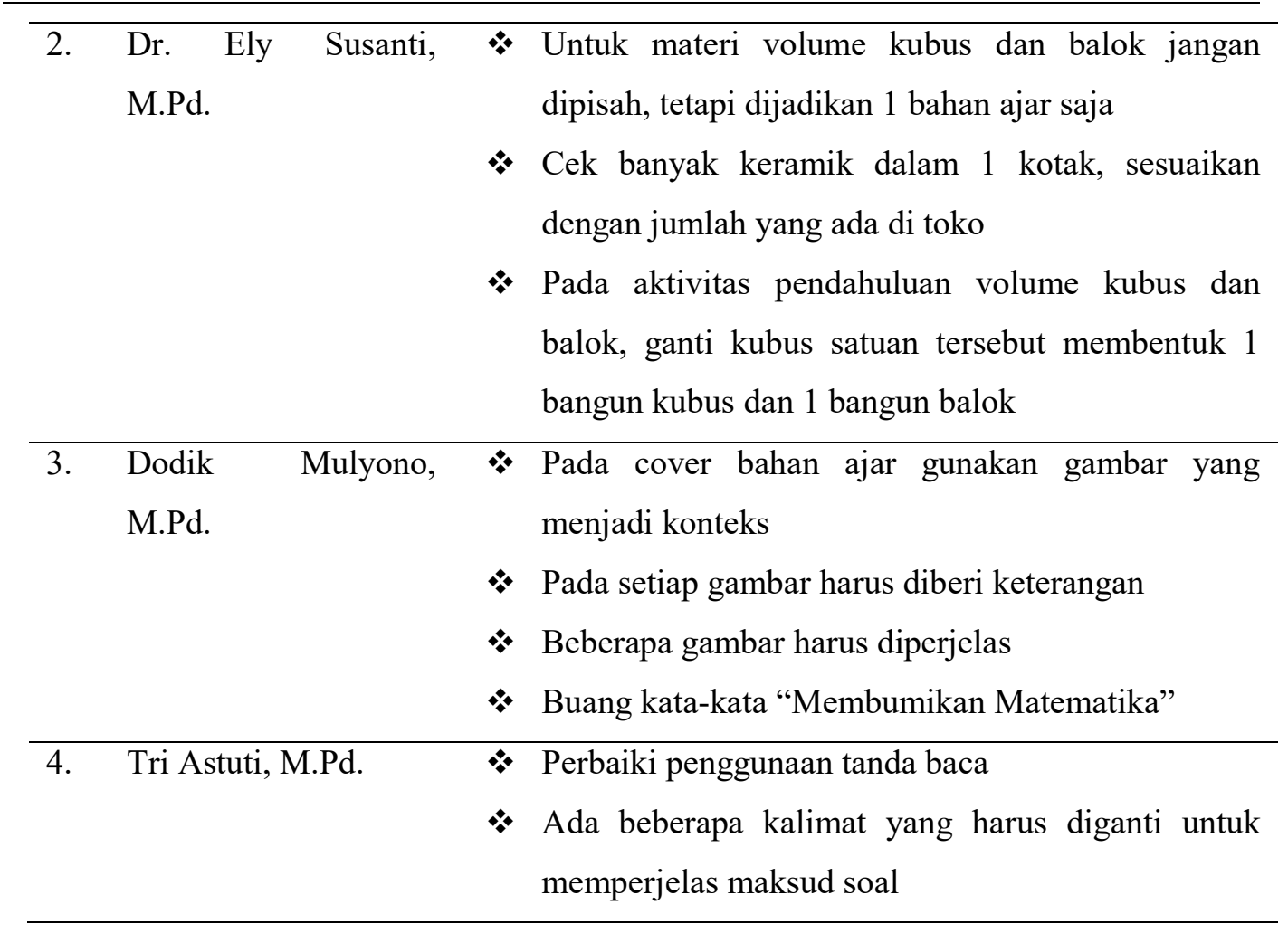

2) One to One

Seiring dengan tahap expert review, maka dilakukan pula tahap one to one. Tahap ini dilakukan pada tanggal 11 April 2017. Pada tahap one to one ini prototype 1 diujicobakan kepada tiga orang siswa kelas VIII SMP Negeri 13 Lubuklinggau dengan kriteria siswa : 1 orang siswa berkemampuan tinggi, 1 orang siswa berkemampuan sedang dan 1 orang siswa berkemampuan rendah. Ujicoba ini dilakukan untuk melihat kesulitan-kesulitan siswa yang mungkin terjadi selama proses penggunaan bahan ajar berbasis pendekatan PMRI dalam pembelajaran. Setelah belajar dengan menggunakan bahan ajar berbasis pendekatan PMRI ketiga siswa tersebut diminta memberikan komentarnya.

Komentar dan saran pada tahap one to one dapat dilihat dalam tabel 3 di bawah ini.

Tabel 3

Komentar Siswa One to One terhadap Prototype 1

\begin{tabular}{ll}
\hline Siswa One to One & \multicolumn{1}{c}{ Komentar } \\
\hline Siswa 1 & $\begin{array}{l}\text { Bahan ajar yang digunakan menarik, jadi tau kegunaan luas } \\
\text { permukaan dan volume kubus dan balok dalam penerapan } \\
\text { kehidupan sehari-hari }\end{array}$ \\
\hline
\end{tabular}




\begin{tabular}{lll}
\hline & $\begin{array}{l}\text { Saya tidak mengerti apa maksud dari kata "sketsa" maksudnya } \\
\text { apa? }\end{array}$ \\
\hline Siswa 2 & Bahan ajar nya berwarna, sehingga lebih enak untuk dipelajari \\
& Soalnya juga berhubungan dengan kehidupan nyata, sehingga \\
& saya jadi tau ternyata pelajaran matematika itu bisa digunakan \\
& dalam kehidupan \\
\hline Siswa 3 & Bahan ajarnya mengasyikkan penuh gambar dan warna, \\
& sehingga semangat untuk mempelajari materinya \\
& Materinya berhubungan dengan kehidupan manusia \\
\hline
\end{tabular}

Berdasarkan komentar dan saran dari pakar sebagai validator serta tiga orang siswa one to one, maka bahan ajar prototype pertama direvisi kembali sehingga menghasilkan prototype kedua. Adapun keputusan revisinya dapat dilihat pada tabel 4 di bawah ini.

Tabel 4

Saran Expert Review, Komentar One to One dan Keputusan Revisi

\begin{tabular}{|c|c|c|c|c|}
\hline $\begin{array}{c}\text { Prototype } 1 \\
\text { (Hasil Validasi) }\end{array}$ & & $\begin{array}{c}\text { Prototype } 1 \\
\text { Komentar/Saran }\end{array}$ & & $\begin{array}{c}\text { Keputusan } \\
\text { Revisi }\end{array}$ \\
\hline $\begin{array}{l}\text { Dr. Somakim, } \\
\text { M.Pd. }\end{array}$ & $\%$ & $\begin{array}{l}\text { Sesuaikan harga pada soal dengan } \\
\text { kehidupan nyata } \\
\text { Pada permasalahan } 4 \text { untuk luas } \\
\text { permukaan kubus dan balok, pada } \\
\text { soal no } 3 \text { dibuang saja karena } \\
\text { maknanya sama dengan soal no } 2\end{array}$ & $*$ & $\begin{array}{l}\text { Sudah diperbaiki } \\
\text { sesuai saran } \\
\text { Sudah diperbaiki } \\
\text { sesuai saran }\end{array}$ \\
\hline $\begin{array}{l}\text { Dr. Ely Susanti, } \\
\text { M.Pd. }\end{array}$ & 4 & $\begin{array}{l}\text { Untuk materi volume kubus dan } \\
\text { balok jangan dipisah, tetapi } \\
\text { dijadikan } 1 \text { bahan ajar saja } \\
\text { Cek banyak keramik dalam } 1 \\
\text { kotak, sesuaikan dengan jumlah } \\
\text { yang ada di toko } \\
\text { Pada aktivitas pendahuluan } \\
\text { volume kubus dan balok, ganti } \\
\text { kubus satuan tersebut membentuk } \\
1 \text { bangun kubus dan } 1 \text { bangun } \\
\text { balok }\end{array}$ & $*$ & $\begin{array}{l}\text { Sudah diperbaiki } \\
\text { sesuai saran } \\
\text { Sudah diperbaiki } \\
\text { sesuai saran } \\
\text { Sudah diperbaiki } \\
\text { sesuai saran }\end{array}$ \\
\hline
\end{tabular}


Efuansyah dan Reny Wahyuni

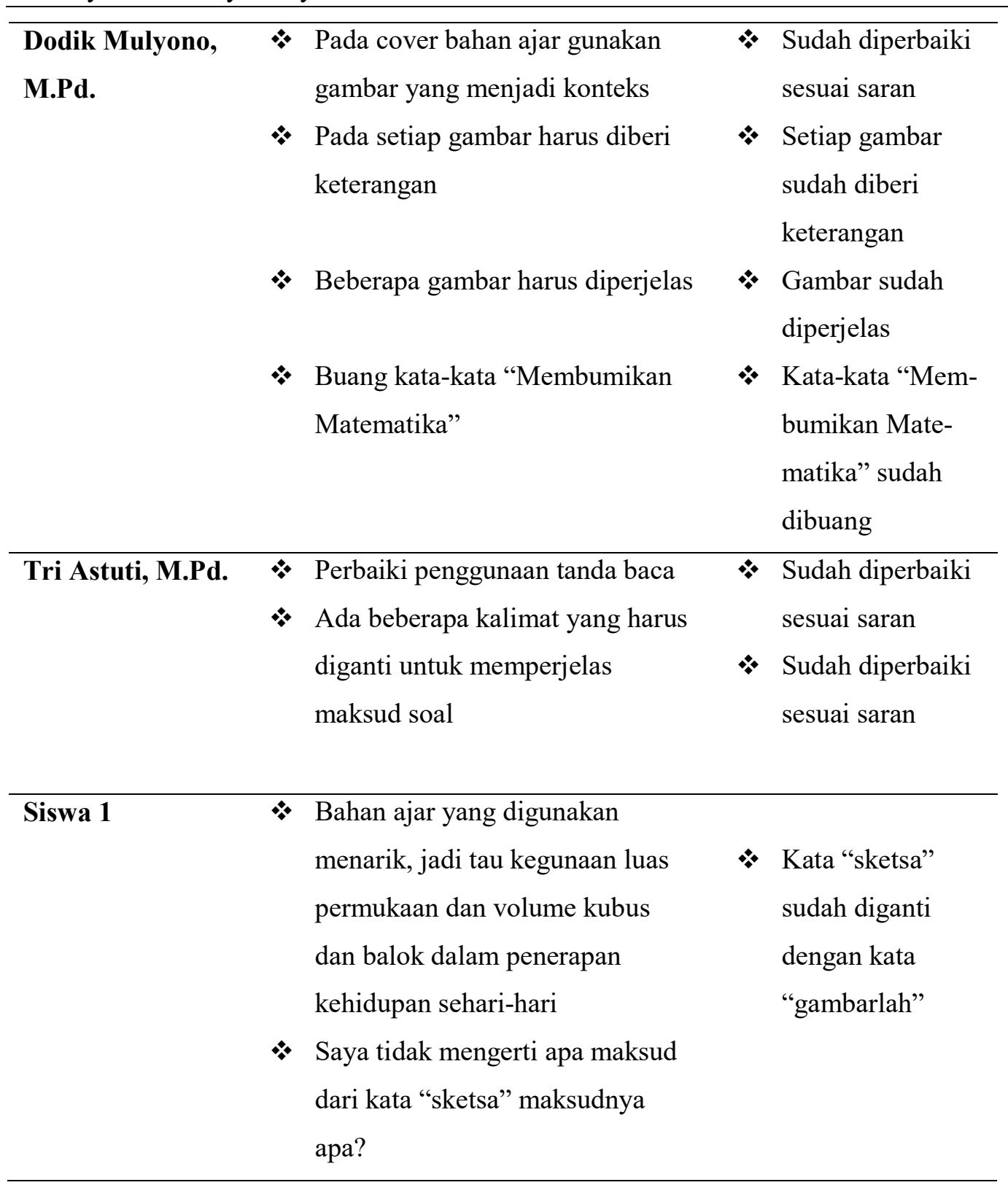

\subsubsection{Tahap Pengembangan (Development)}

Setelah bahan ajar direvisi melalui tahapan expert review dan one-to-one evaluation, maka dapat disimpulkan prototype pertama yang dikembangkan sudah tergolong valid. Hasil perbaikan prototype pertama ini diperoleh prototype kedua.

\subsubsection{Tahap Implementasi (Implementation)}

Pada tahapan ini, bahan ajar yang telah direvisi berdasarkan saran dan komentar para ahli maka bahan ajar selanjutnya diuji-cobakan di SMP N 13 Lubuklinggau. Tahapan implementasinya sebagai berikut : 
a. Small Group

Pada tahapan ini, prototype kedua yang dihasilkan dari dua tahap sebelumnya diujicobakan kepada enam orang siswa kelas VIII SMP Negeri 13 Lubuklinggau bukan subjek penelitian dalam satu kelompok dengan kemampuan heterogen. Siswa diminta untuk mengerjakan bahan ajar yang telah dibuat, dari hasil pekerjaan mereka terlihat bahwa mereka dapat menggunakan bahan ajar tersebut. Keterpakaian bahan ajar pada tahap small group ini menunjukkan bahwa bahan ajar ini dapat dikatakan praktis. Setelah belajar dengan menggunakan bahan ajar ini, siswa diminta memberikan komentar mereka terhadap bahan ajar menggunakan pendekatan PMRI. Adapun hasil komentar siswa dapat dilihat pada Tabel 6 di bawah ini.

Tabel 6

Komentar Siswa Small Group terhadap Prototype II dan Keputusan Revisi

\begin{tabular}{llll}
\hline Komentar & Keputusan Revisi & \\
\hline Masih bingung langsung materi luas & Siswa diingatkan kembali mengenai \\
permukaan kubus dan balok & bentuk kubus dan balok untuk \\
& mengingatkan kembali pelajaran \\
& sebelumnya & \\
Pada materi volume kubus dan balok \\
permasalahannya terlalu banyak \\
sehingga tidak fokus dalam \\
mengerjakan soal
\end{tabular}

Setelah tahap small group dilaksanakan, maka selanjutnya prototype kedua dievaluasi dan diperbaiki sesuai komentar dan saran pada saat small group. Hasil dari perbaikan prototype kedua ini diperoleh prototype ketiga.

\section{b. Field Test}

Setelah melakukan uji coba small group, maka tahapan selanjutnya adalah tahap field test (ujicoba lapangan) pada kelas sesungguhnya. Field test dilaksanakan di kelas VIII.4 SMP Negeri 13 Lubuklinggau yang berjumlah 20 siswa, yang dibagi menjadi 5 kelompok yang memiliki kemampuan berbeda-beda. Proses pengambilan 
data pada penelitian ini dilakukan sebanyak 4 kali pertemuan yang dimulai pada tanggal 25 April 2017.

Pada setiap pembelajaran, setiap kelompok diberikan bahan ajar yang akan diselesaikan siswa melalui diskusi kelompok dan hasilnya dipresentasikan secara bergantian oleh perwakilan kelompok.

\subsection{Pembahasan}

Berdasarkan proses pengembangan bahan ajar yang telah melalui beberapa tahapan dimulai dari tahap persiapan (preliminary) hingga tahap prototyping dengan alur formative evaluation yang meliputi self evaluation, expert review, one-to-one, small group, dan field test, telah dihasilkan perangkat bahan ajar pada materi kubus dan balok menggunakan Pendekatan Matematika Realistik Indonesia (PMRI) telah dinyatakan valid secara kualitatif dan praktis. Bahan ajar yang dikembangkan mengadopsi prosedur pengembangan ADDIE yang terdiri atas tahap analisis (analysis), tahap desain (design), tahap pengembangan (development), tahap implementasi (implementation), dan tahap evaluasi (evaluation). Untuk mengetahui efektivitas bahan ajar menggunakan Pendekatan Matematika Realistik Indonesia (PMRI), maka bahan ajar diimplementasikan dalam pembelajaran matematika di sekolah. Sebelum diimplementasikan (diuji-cobakan), bahan ajar tersebut terlebih dahulu divalidasi oleh pakar yang terdiri dari ahli media, ahli bahasa, dan ahli konten (isi). Setelah divalidasi oleh para pakar maka bahan ajar tersebut direvisi sesuai saran para pakar, lalu bahan ajar yang telah direvisi diuji-cobakan pada tahap one-to-one dan menghasilkan prototype 2. Hasil dari prototype 2 lalu diuji-cobakan lagi pada tahap small group dan menghasilakan prototype 3. Hasil revisi dari prototype 3 diuji-cobakan pada kelas sesungguhnya atau yang disebut tahap field test.

Validasi bahan ajar ini dilakukan untuk mengetahui kualitas bahan ajar dilihat dari komponen kelayakan isi, kelayakan penyajian, kelayakan bahasa, dan kelayakan kegrafikan. Hasil validasi bahan ajar dari para ahli berupa pernyataan ahli materi, ahli bahasa, dan ahli konten bahwa bahan ajar layak untuk diuji-cobakan dengan beberapa revisi yang harus dilakukan. Validasi pakar ini sejalan dengan one-to-one, dimana tujuan one-to-one ini adalah untuk melihat keterbacaan bahan ajar dilihat dari sudut pandang siswa yang terdiri dari siswa dengan kemampuan rendah, siswa dengan kemampuan sedang dan siswa dengan kemampuan tinggi. Setelah melalui revisi dan menghasilkan prototype 2 maka tahapan selanjutnya adalah small group dengan tujuan untuk melihat keterbacaan bahan ajar pada kelompok kecil yang terdiri dari 5-7 orang siswa tiap 
kelompoknya. Dari small group bahan ajar direvisi dan menghasilkan prototype 3, lalu bahan ajar diuji-cobakan pada kelas sesungguhnya yaitu tahapan field test, tahapan ini bertujuan untuk melihat efektivitas bahan ajar yang digunakan pada kelas yang sesungguhnya. Bahan ajar yang dikembangkan tidak terlepas dari proses penyusunan bahan ajar yang memperhatikan tiga prinsip penyusunan bahan ajar, yaitu prinsip relevansi, prinsip konsistensi, dan prinsip kecukupan (Direktorat PSMA, 2006). Bahan ajar yang memenuhi prinsip relevansi karena bahan ajar berkaitan dengan Standar Kompetensi dan Kompetensi Dasar. Pada tahap analisis penelitian ini dilakukan analisi kurikulum mencakup analisis Standar Kompetensi dan Kompetensi Dasar yang digunakan pada materi kubus dan balok. Hasil dari analisis kurikulum digunakan untuk menyusun peta kebutuhan bahan ajar pada tahapan design. Selanjutnya, peta kebutuhan ini digunakan pada pembuatan alur pembelajaran yang termuat dalm bahan ajar. Melalui alur tersebut menjadikan bahan ajar disusun memenuhi prinsip relevansi. Penyusunan bahan ajar ini juga menggunakan prinsip konsistensi karena bahan ajar yang dibuat konsisten dengan pencapaian Standar Kompetensi dan Kompetensi Dasar. Selain itu, bahan ajar ini juga disusun berdasarkan prinsip kecukupan karena bahan ajar yang disusun memuat materi yang tidak terlalu sedikit dan tidak terlalu banyak sehingga bahan ajar yang akan digunakan mudah dipahami oleh siswa.

Selama penggunaan bahan ajar, siswa berlatih menyelesaikan masalah kontekstual pada materi kubus dan balok. Masalah-masalah yang disajikan dalam bahan ajar berkaitan dengan konteks yang mudah dijumpai siswa dalam kehidupan sehari-hari. Penggunaan bahan ajar melalui pembelajaran dengan Pendekatan Matematika Realistik Indonesia (PMRI) memudahkan siswa dalam menemukan konsep matematika yang termuat pada setiap masalah yang disajikan dalam bahan ajar tersebut.

\section{Kesimpulan}

Berdasarkan hasil penelitian dan pembahasan yang telah diuraikan di atas, maka dapat disimpulkan bahwa pengembangan bahan ajar menggunakan Pendekatan Matematika Realistik Indonesia (PMRI) siswa kelas VIII pada materi Kubus dan Balok dilakukan dengan mengadopsi prosedur pengembangan ADDIE yang terdiri atas tahap analisis (Analysis), tahap desain (Design), tahap pengembangan (Development), tahap implementasi (Implementation), dan tahap evaluasi (Evaluation). Pada tahapan proses pengembangan menggunakan evaluasi dari Tessmer yang melakukan one to one, small group, field test. Setelah bahan ajar dibuat dan menghasilkan prototype 1 bahan ajar tersebut divalidasi oleh pakar yang terdiri dari ahli konten, ahli media dan ahli bahasa. 
Sejalan dengan proses validasi pakar maka bahan ajar juga diujicobakan kepada tiga orang siswa pada tahap one to one. Setelah dilakukan validasi pakar dan one to one, maka bahan ajar direvisi sesuai saran dan petunjuk tim ahli dan keterbacaan dari siswa pada saat one to one dan menghasilkan prototype 2. Setelah itu, prototype 2 diujicobakan pada kelompok kecil yang berjumlah 6 orang siswa tahap small group dan menghasilkan prototype 3 . Selanjutnya prototype 3 diujicobakan pada kelas sesungguhnya yaitu pada tahap field test. Dari serangkaian proses pengembangan yang dilakukan maka bahan ajar tersebut menghasilkan bahan ajar yang valid dan praktis.

\section{Referensi}

Chomsin, W. S., \& Jasmadi. 2008. Panduan Menyusun Bahan Ajar Berbasis Kompetensi. Jakarta: Gramedia.

Depdiknas. 2006. Permendiknas No. 22 tentang : Standar Isi. Jakarta: Depdiknas.

Dewanti, S. S. 2015. Pengembangan Bahan Ajar Geometri Analitik Berbasis Guided Discovery untuk Memfasilitasi Kemampuan Berpikir Kritis. Seminar Nasional Matematika dan Pendidikan Matematika UMS (hal. 187-199). Surakarta: Universitas Muhammadyah Surakarta.

Haji, Saleh. 2011. Model Bahan Ajar Matematika SMP Berbasis Realistic Mathematics Education untuk Mengembangkan Kemahiran Matematika. Jurnal Exacta, IX (1), 45-50.

Kusumaningtyas, W. K., Wardono, \& Sugiarto. 2013. Penerapan PMRI terhadap Kemampuan Pemecahan Masalah Matematika Berbantuan Alat Peraga Materi Pecahan. Unnes Journal of Mathematics Education , 1 (1).

Muchlis, E. E. 2012. Pengaruh Pendekatan Pendidikan Matematika Realistik Indonesia (PMRI) terhadap Perkembangan Kemampuan Pemecahan Masalah Siswa Kelas II SD Kartika 1.10 Padang. Jurnal Exacta , X(2), 136-139.

Muharom, T. 2014. Pengaruh Pembelajaran dengan Model Kooperatif Tipe Student Teams Achievement Division (STAD) terhadap Kemampuan Penalaran dan Komunikasi Matematik Peserta Didik di SMK Negeri Manonjaya Kabupaten Tasikmalaya. Jurnal Pendidikan dan Keguruan, 1 (1).

Mustika, A. M. 2012. Penerapan PMRI dalam Pembelajaran Matematika di Sekolah Dasar untuk Menumbuhkembangkan Pendidikan Karakter. Seminar Nasional Matematika dan Pendidikan Matematika. Yogyakarta: Pendidikan Matematika FMIPA UNY. 120-130

Permana, Y., \& Sumarmo, U. 2007. Mengembangkan Kemampuan Penalaran dan Koneksi Matematika Siswa SMA Melalui Pembelajaran Berbasis Masalah. Jurnal Education UPI , 1 (2), 116-123.

Pribadi, Benny A. 2010. Model Desain Sistem Pembelajaran. Jakarta : Dian Rakyat

Putri, R. I. 2010. Menjadi Guru Profesional Melalui Penilaian. Palembang: FKIP Unsri.

Ratnaningsih, N. 2008. Berbagai Keterampilan Berpikir Matematik. Seminar Pendidikan Matematika di Universitas Siliwangi Tasikmalaya. Tasikmalaya: Universitas Siliwangi. 
Shadiq, F. 2009. Model-Model Pembelajaran Matematika SMP. Jakarta: Nurul Hidayah.

Sugiman. 2008. Pandangan Matematika sebagai Aktivitas Insani beserta Dampak Pembelajarannya. Jurnal Pendidikan Matematika , 2, 61-71.

Sumartini, T. S. 2015. Peningkatan Kemampuan Penalaran Matematis Siswa Melalui Pembelajaran Berbasis Masalah. Jurnal Pendidikan Matematika , 5 (1), 1-10.

Utami, N. P., Mukhni, \& Jazwinarti. 2014. Kemampuan Penalaran Matematis Siswa Kelas XI IPA SMAN 2 PAINAN Melalui Penerapan Pembelajaran Think Pair Square. Jurnal Pendidikan Matematika , 3 (1), 7-12.

Wardhani. 2008. Penelitian Tindakan Kelas. Jakarta: Universitas Terbuka.

Widoyoko, E.P. 2009. Evaluasi Program Pembelajaran. Yogyakarta: Pustaka Belajar

Wijaya, A. 2012. Pendidikan Matematika Realistik: Suatu Alternatif Pendekatan Pembelajaran Matematika. Yogyakarta: Graha Ilmu. 